\title{
EVALUATION OF PRO-APOPTOTIC EFFECTS OF $\beta$-MONOLINOLEIN ON METASTATIC BREAST CANCER CELL LINE MDA-MB-231
}

\author{
MOHAMMED SHAFI SOFI* \\ Department of Microbiology and Biotechnology, Molecular Diagnostics and Nanobiotechnology Laboratories, Bangalore University, J.B. \\ Campus, Bengaluru, Karnataka, India.Email: mshafi.sofii@gmail.com
}

Received: 06 October 2018, Revised and Accepted: 06 December 2018

\section{ABSTRACT}

Objectives: The objective of this study was to evaluate the $\beta$-monolinolein as a potential therapy for breast cancer treatment.

Methods: The cytotoxic activity of $\beta$-monolinolein was evaluated by 3-(4,5-dimetylthiazol-2-yl)-2,5-diphenyltetrazolium bromide and trypan blue exclusion assay. The cellular cytotoxicity and levels of cytosolic enzyme, lactate dehydrogenase (LDH), were measured by assessing $\mu$ moles of nicotinamide adenine dinucleotide/well/min. To confirm whether $\beta$-monolinolein induces apoptosis in 3,4-methylenedioxyamphetamine (MDA)MB-231 cells, western blot and semiquantitative reverse transcription-polymerase chain reaction (RT-PCR) analysis were performed.

Results: For the $1^{\text {st }}$ time, it was demonstrated that $\beta$-monolinolein strongly inhibits the growth of MDA-MB-231 cells, with an half maximal inhibitory concentration value of $12.5 \mu \mathrm{g} / \mathrm{ml}$. $<90 \%$ of cell death was achieved at higher concentrations after $48 \mathrm{~h}$ of treatment. Trypan blue assay showed that the cell viability was significantly decreased in a dose-dependent manner in MDA-MB-231 cells after $48 \mathrm{~h}$ of treatment. On the other hand, LDH activities in the cultured media were significantly elevated in a dose-dependent manner as compared to the control. Further, the western blot analysis showed that $\beta$-monolinolein leads to change in expression levels of important cell cycle regulators such as $p 21, B a x, B c l-X l$, and $B c l-2$ in MDA-MB-231 cells. The semiquantitative RT-PCR results indicated a significant upregulation of proapoptotic genes such as $p 53$, $p 21$, and Bax and downregulation of antiapoptotic gene $\mathrm{Bcl}-2$.

Conclusion: These results indicate that $\beta$-monolinolein leads to change in expression of various cell cycle/apoptotic regulators and hence induces death in MDA-MB-231 cells.

Keywords: $\beta$-monolinolein, Cytotoxicity, Breast cancer treatment.

(C) 2019 The Authors. Published by Innovare Academic Sciences Pvt Ltd. This is an open access article under the CC BY license (http://creativecommons. org/licenses/by/4. 0/) DOI: http://dx.doi.org/10.22159/ajpcr.2019.v12i3.30130

\section{INTRODUCTION}

Cancer is defined as a complex series of life-threatening disease condition and a leading cause of death caused by persistent tissue injury and host-environment interactions [1]. Worldwide, cancer is known to be the second leading cause of death and is responsible for an estimated 9.6 million deaths in 2018. Globally, about one in six deaths are due to cancer [2]. The repeated exposure of carcinogens such as tobacco, ultraviolet light, and infections leads to various genetic (mutations), epigenetic (loss of heterozygosity), and global transcriptome changes (through inflammation pathways) and is associated with increased cancer risk [3]. Among cancers, breast cancer is projected to be among the most common cancer and is the most frequent malignant neoplasm in women [4]. Due to increased occurrence of cancer and worldwide prevalence during the past decade, it has posed a great challenge to the health-care professionals. The latest WHO statistics suggests about $45 \%$ increase in the global cancer deaths by 2030 , of which $70 \%$ would be contributed from developing countries like India [5]. Despite a better understanding of disease and the advent of modern technology and rationally targeted drugs, the incidence and cure rate of cancer have not improved. Cancer cure and prevention, therefore, remain a high priority for scientific community across the world [6].

Although a range of conventional therapies based on chemotherapy, surgery, and radiotherapy is available, these approaches are in many cases of limited efficacy [7]. Moreover, the current anticancer regimens are frequently associated with significant levels of toxicity and the emergence of drug resistance. One major challenge to relieve cancer burden is to develop highly effective drugs with specificity on cancers butlittle or no side effects on normal mammalian cells [8]. Many research projects have been focused on developing new chemotherapies either by exploring the anticancer ability of novel compounds or by assessing drugs conventionally used in other clinical diseases. Hence, the search for cancer treatment continues to be a worldwide effort. As part of this effort, various natural products, especially from medicinal plants, have been tested against various cancer cell lines $[9,10]$. Still, there has been a long-standing interest in the identification of medicinal plants and derived natural products for developing novel cancer therapeutics [11,12]. Natural products have been playing a major role in the search for novel drugs for numerous illnesses including cancer $[13,14]$. Throughout human history and especially in the past century, natural products have virtually remained undisputed leaders among the various therapeutic tools humans have employed against many diseases including cancer [15]. Natural products have been found to be a relevant source of novel and potent bioactive compounds with minimal side effects in vivo. Many phytocompounds used for the treatment of malignant tumors are cytotoxic drugs that can induce tumor cell death by apoptosis [16]. Chemotherapy with cytotoxic drugs is the main treatment modality for certain types of cancer [17]. In vitro cellbased assays have been developed to rapidly determine the cytotoxic activity of several compounds. Cell-based assays are also useful in identifying variations in susceptibility of different target cells to several chemotherapeutic agents $[18,19]$. The specific intracellular damage induced by these drugs is generally well characterized. For example, cisplatin, one of the most widely used anticancer drugs, reacts with the target genomic DNA to form DNA adducts [20]. This DNA damage can induce cell cycle arrest and apoptosis [21,22]. Inhibition of proliferation and/or induction of apoptosis in cancer cells are the most important characteristic of many anticancer agents [23]. However, the mechanisms by which the specific damage induced by the chemotherapeutic agents 
that are converted into a death signal remain poorly understood. Breast cancer has been found attenuated by an appreciable amount of natural substances including phytochemicals and dietary substances which affect cell proliferation, cell differentiation, angiogenesis, apoptosis, and a few other cellular transduction pathways [24]. The increasing global incidence of breast cancer emphasizes the need to understand the mechanism involved in breast tumorigenesis and to identify novel, safe, and efficient anticancer drugs for the treatment of breast cancer. Nevertheless, the continued search for safer and more effective natural agents to improve the efficiency of breast cancer treatment is furthermore a need [25].

Despite the reports on the biological activities of these essential oils, data on their cytotoxicity are still scarce in the literature [26,27]. Discovery and development of new chemopreventive drugs against breast cancer with an interesting safety and efficacy to improve breast cancer management and reduce the high cost and pain of patients are an urgent necessity [28]. Hence, the objective of the present study is to evaluate the cytotoxic and proapoptotic activity and potency of $\beta$-monolinolein on metastatic breast cancer cell line 3,4-methylenedioxyamphetamine (MDA)-MB-231.

\section{METHODS}

\section{Drug preparation}

$\beta$-monolinolein (9,12-octadecadienoic acid (Z, Z)-, 2-hydroxy-1(hydroxymethyl) ethyl ester) was isolated, identified, and characterized from the leaves of Abrus precatorius L. using various techniques such as Soxhlet extraction, thin-layer chromatography, column chromatography, high-performance liquid chromatography (HPLC), nuclear magnetic resonance spectroscopy (NMR), and by gas chromatography-mass spectrum analysis, as discussed in our published research work [29].

\section{Cell culture and maintenance}

MDA-MB-231 cells were maintained in Dulbecco's Modified Eagle's medium with $10 \%$ fetal bovine serum, $100 \mathrm{U} / \mathrm{ml}$ penicillin, and $100 \mu \mathrm{g} / \mathrm{ml}$ streptomycin in a humidified atmosphere of $95 \%$ air and $5 \% \mathrm{CO}_{2}$ at $37^{\circ} \mathrm{C}$.

\section{(3-(4,5-dimetylthiazol-2-yl)-2,5-diphenyltetrazolium bromide} (MTT) assay for cytotoxicity

Analysis of cell viability was done by standard colorimetric MTT assay. After $24 \mathrm{~h}$, cells were treated with different concentrations of $\beta$-monolinolein for $48 \mathrm{~h} .20 \mu \mathrm{l}$ of MTT $(5 \mathrm{mg} / \mathrm{ml})$ reagent was added to each well and then incubated for $3 \mathrm{~h}$ at $37^{\circ} \mathrm{C}$ in $\mathrm{CO}_{2}$ incubator [18]. After $3 \mathrm{~h}$, the medium was removed and $200 \mu \mathrm{l}$ of dimethyl sulfoxide (DMSO) was added and mixed. Absorbance was recorded at $595 \mathrm{~nm}$ with multiwell-plate reader. The percentage of cell viability of $\beta$-monolinolein was calculated according to the following equation: Percentage of cell viability=(OD of treated cells/OD of control cells) $\times 100$. The concentration of drug that inhibits $50 \%$ of the cells (half maximal inhibitory concentration [ $\left.\mathrm{IC}_{50}\right]$ values) for these samples was obtained from dose-response curves [30].

\section{Trypan blue dye exclusion assay}

For the determination of cell viability, MDA-MB-231 breast cancer cells were plated at a density of $1 \times 10^{6}$ cells/well in 24-well tissue culture plates and cultured for $48 \mathrm{~h}$ at $37^{\circ} \mathrm{C}$. The medium was replaced with serum-free medium and cells were treated with various concentrations of $\beta$-monolinolein $(10,20,30,40$, and $50 \mu \mathrm{g} / \mathrm{ml})$ for a further $48 \mathrm{~h}$. The cultures were harvested and washed twice with phosphate-buffered saline (PBS), cell pellet was then suspended with $0.5 \mathrm{ml}$ PBS. Then, $20 \mu \mathrm{l}$ of cell was mixed with equal volume of $0.4 \%$ trypan blue (SigmaAldrich, USA). The number of live/dead cells was directly counted on hemocytometer under microscope. The percentage viability for the cells was calculated as (live cells/total cells) $\times 100$.

\section{Lactate dehydrogenase (LDH) cytotoxicity assay}

MDA-MB-231 cells $\left(1 \times 10^{6}\right.$ cells/well) were plated in $100 \mu$ l of medium per well in 96-well plates and were allowed to attach to the plate for
$24 \mathrm{~h}$. After cell attachment ( $24 \mathrm{~h})$, cells were treated with increasing concentrations of $\beta$-monolinolein $(10,20,30,40$, and $50 \mu \mathrm{g} / \mathrm{ml})$ for a further $48 \mathrm{~h}$. The extracellular LDH activity was measured in the medium after $24 \mathrm{~h}$. Following treatment, culture supernatants were then collected from each well and transferred to individual tubes containing Tris-ethylenediaminetetraacetic acid-nicotinamide adenine dinucleotide (NADH) buffer followed by 10 min incubation at $37^{\circ} \mathrm{C}$ and the addition of pyruvate solution. Absorbance was read at $339 \mathrm{~nm}$ using an ultraviolet (UV)-visible spectrophotometer (UV-260, Shimadzu Corp, Japan). LDH activity was expressed as $\mu$ moles of NADH used per minute per well. All experiments were repeated 3 times in triplicates.

\section{Western blot analysis}

Change in the protein levels of various cell cycles/apoptotic regulators such as $\mathrm{p} 21, \mathrm{BAX}, \mathrm{Bcl}-\mathrm{Xl}$, and $\mathrm{BCl}-2$ was analyzed by western blot analysis. Specific antibodies to $\mathrm{p} 21, \mathrm{BAX}, \mathrm{Bcl}-\mathrm{Xl}, \mathrm{BCl}-2$, and $\beta$-actin (loading control) were used. The membranes were washed with TrisBuffered Saline Tween-20 and incubated with specific secondary antibodies. Femtolucent substrate (G-biosciences, USA) was used to detect the antibodies by exposing the blot to an X-ray film. Developer and fixer were purchased from Eastman Kodak (USA).

Gene expression analysis by semiquantitative reverse transcriptionpolymerase chain reaction (RT-PCR)

Expression level of various apoptosis-related genes was analyzed by semiquantitative RT-PCR. For expression analysis, gene-specific primers were used as listed in Table 1.

\section{Statistical analysis}

The data represent the mean \pm standard deviation of three independent experiments each in a triplicate. The significance between control and treated groups was analyzed by Student's t-test and $\mathrm{p}<0.05$ was taken as statistically significant by GraphPad Prism 5.0 Software (GraphPad Software Inc., CA, USA).

\section{RESULTS}

\section{MTT assay for cytotoxicity}

Treatment of MDA-MB-231 cells for $48 \mathrm{~h}$ with $\beta$-monolinolein showed a very significant and higher cytotoxic activity with an $\mathrm{IC}_{50}$ value of $12.5 \mu \mathrm{g} / \mathrm{ml}$ (Fig. 1). These results indicated that $\beta$-monolinolein has a potent cytotoxic activity on MDA-MB-231 breast cancer cells.

\section{Morphological studies}

Microscopic examination of MDA-MB-231 cells treated with $\beta$-monolinolein showed significant morphological changes such as shrinkage and detachment from the surface (Fig. 2). Due to the loss of cells, differences in the cell number can also be visualized in culture dish when it was treated with $\beta$-monolinolein for $48 \mathrm{~h}$ in comparison to the control dish. These results show that $\beta$-monolinolein has a potent cytotoxic activity on breast cancer cells.

Table 1: Amplicon size and sequence of the primers used in semiquantitative RT-PCR

\begin{tabular}{|c|c|c|c|}
\hline Sl. No & Gene & Amplicon size & Primer sequence \\
\hline 1. & $p 21$ & $147 \mathrm{bp}$ & Forward: GCCATTAGCGCATCACAGT \\
\hline 2. & $B I D$ & $133 \mathrm{bp}$ & $\begin{array}{l}\text { Reverse: TGCGTTCACAGGTGTTTCTG } \\
\text { Forward: TTGTGATGCACTCATCCCTG }\end{array}$ \\
\hline 3. & $B A X$ & $132 \mathrm{bp}$ & $\begin{array}{l}\text { Reverse: CCATAAGGAGGAAGCGGGTA } \\
\text { Forward: CTCAGCCCATCTTCTTCCAG } \\
\text { Reverse: GCTGGATCCAAGACCAGG }\end{array}$ \\
\hline 4. & $B c l-2$ & $141 \mathrm{bp}$ & $\begin{array}{l}\text { Forward: CCAGAGGAGGAGGTAGGGAC } \\
\text { Reverse: TGATGTGAGTCTGGGCTGAG }\end{array}$ \\
\hline 5. & Rpl35a & $141 \mathrm{bp}$ & $\begin{array}{l}\text { Forward: CTGGTTTTGTTTGGTTTGCC } \\
\text { Reverse: AAGGGAGCACACAGCTCTTC }\end{array}$ \\
\hline
\end{tabular}

RT-PCR: Reverse transcription-polymerase chain reaction 
Trypan blue dye exclusion assay

Direct counting for non-viable and viable cells using trypan blue exclusion test showed that $\beta$-monolinolein treated cells with the different concentrations ranging from 10 to $50 \mu \mathrm{g} / \mathrm{ml}$ for $48 \mathrm{~h}$ reduced the cell viability in dose-dependent manner (Fig. 3). At $10 \mu \mathrm{g} / \mathrm{ml}$ viability was decreased to $62.41 \%$, whereas at $50 \mu \mathrm{g} / \mathrm{ml}$ viability reached to minimum value of $11.84 \%$. This assay showed that $\beta$-monolinolein killed human breast cancer cells at a higher rate than control (without DMSO) and DMSO. The data suggest that $\beta$-monolinolein treatment results in dosedependent growth inhibition and induces cell death in MDA-MB-231cells.

\section{LDH cytotoxicity assay}

LDH level was increased from $1.0 \mu$ moles (control) to $8.83 \mu$ moles (treated at $50 \mu \mathrm{g} / \mathrm{ml}$ of extract) of NADH. Cells treated with $\beta$-monolinolein for $48 \mathrm{~h}$ resulted in a significant increase (7.83-fold) in LDH release relative to the untreated cells in dose-dependent manner (Fig. 4). Cytotoxic effects of $\beta$-monolinolein due to membrane damage leads to cytosolic $\mathrm{LDH}$ release could be one of the reasons, leading to cell death.

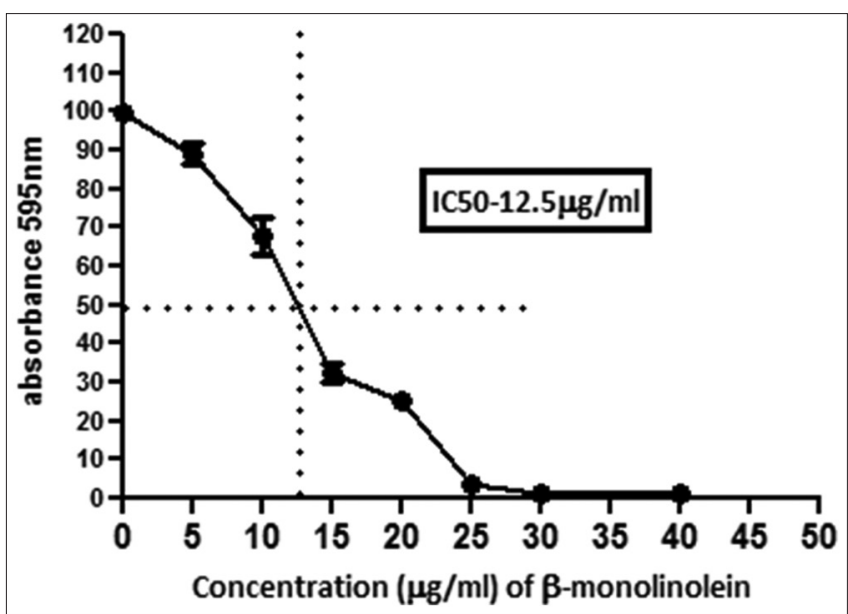

Fig. 1: Cytotoxic activity of $\beta$-monolinolein on 3,4-methylenedioxyamphetamine (MDA)-MB-231 cells. $\beta$-monolinolein showed significant cytotoxic activity at concentration of 5-50 $\mu \mathrm{g} / \mathrm{ml}$ after $48 \mathrm{~h}$ of treatment. Dosedependent cytotoxic activity of $\beta$-monolinolein on MDA-MB-231 cells was observed, with an half maximal inhibitory concentration value of $12.5 \mu \mathrm{g} / \mathrm{ml}$. Values are mean \pm standard error mean of at least three independent experiments, each in triplicates
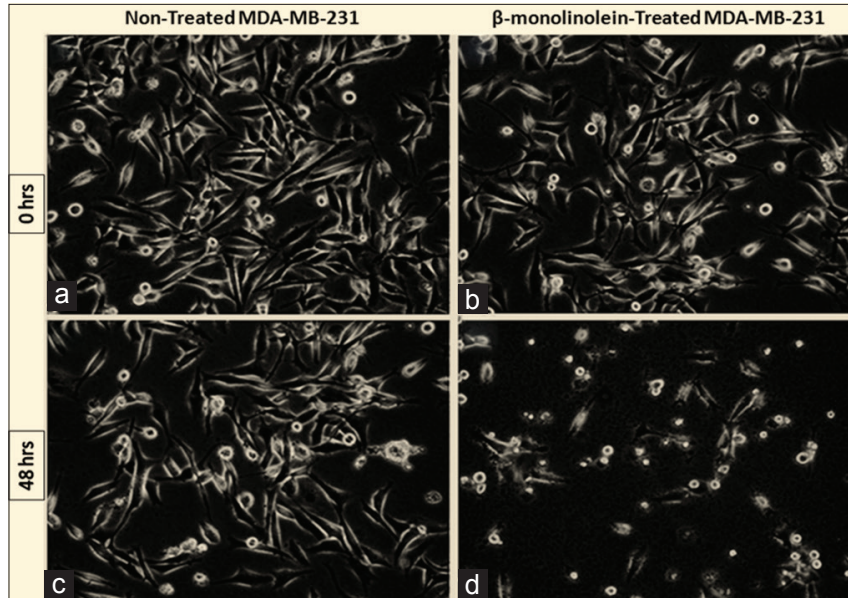

Fig. 2: Microscopic view of human breast cancer 3,4-methylenedioxyamphetamine-MB-231 cells ( $\times 10$ magnification), (a) non-treated control cells at $0 \mathrm{~h}$ and (b) $48 \mathrm{~h}$; (c) $\beta$-monolinolein treated cells at $0 \mathrm{~h}$ and (d) $48 \mathrm{~h}$ at with half maximal inhibitory concentration $(12.5 \mu \mathrm{g} / \mathrm{ml})$
Western blot analysis

Western blot analysis shows that $\beta$-monolinolein treatment leads to upregulation of proapoptotic proteins such as p21 and Bax. Downregulation of antiapoptotic proteins Bcl-Xl and Bcl-2 in MDAMB-231 cells was also determined after treatment with $\beta$-monolinolein (Fig. 5a). As shown in Fig. 5b, the treatment leads to a 9-fold upregulation of p21, 3-fold upregulation of Bax, 5-fold downregulation of $\mathrm{Bcl}-\mathrm{Xl}$, and 6-7-fold downregulation of Bcl-2 at $20 \mu \mathrm{g} / \mathrm{ml}$ concentration of $\beta$-monolinolein. Together these results show that $\beta$-monolinolein has a potent effect on expression of various regulators of the cell cycle and apoptosis.

Gene expression analysis by semiquantitative RT-PCR

Semiquantitative RT-PCR analysis indicates a significant upregulation of proapoptotic genes such as $p 21, B I D$, and Bax on treatment with

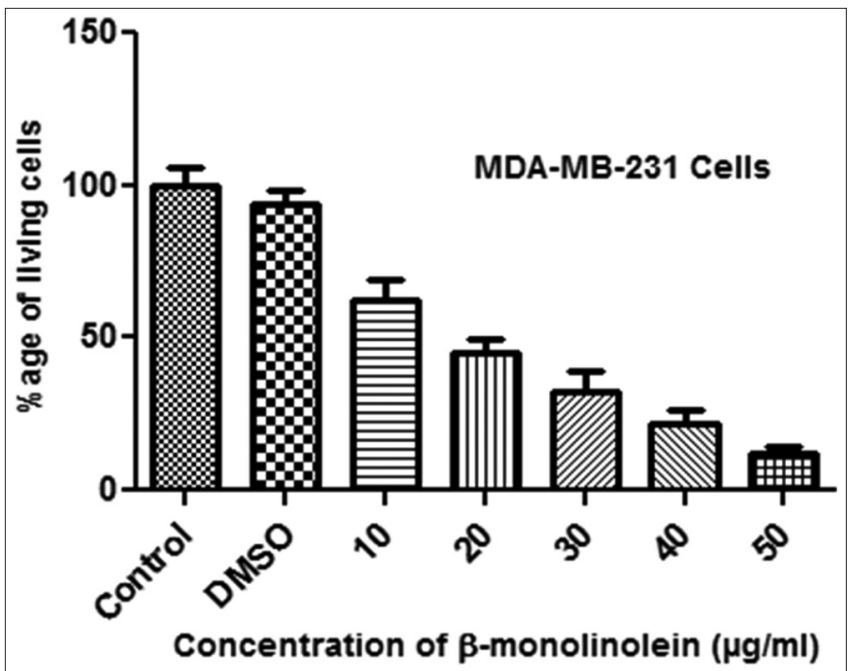

Fig. 3. Effect of $\beta$-monolinolein on cell viability of 3,4-methylenedioxyamphetamine-MB-231 cells by trypan blue assay. Viability reached a minimum value of $11.84 \%$ (at $50 \mu \mathrm{g} / \mathrm{ml}$ ) in treated cells. Data are representative of three independent experiments with three replicates. Error bars represent mean \pm standard deviation

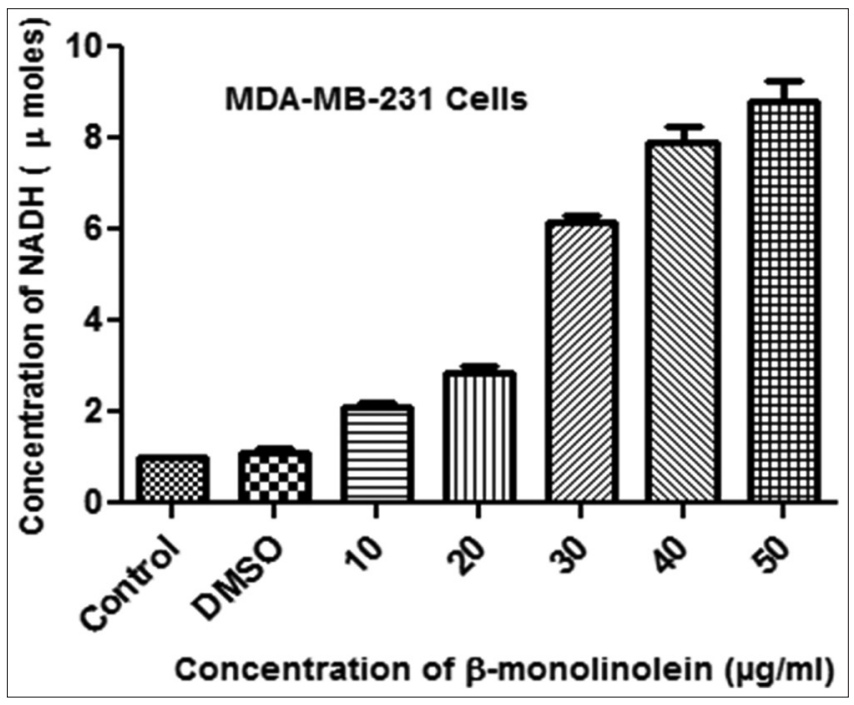

Fig. 4: Lactate dehydrogenase activity in control and $\beta$-monolinolein treated 3,4-methylenedioxyamphetamine-MB-231 cells. Lactate dehydrogenase level was increased from $1.0 \mu$ moles (control) to $8.83 \mu$ moles of NADH in treated cells with $50 \mu \mathrm{g} / \mathrm{ml}$. Data are representative of three independent experiments with three replicates. Error bars represent mean \pm standard deviation 
$\beta$-monolinolein. In addition, downregulation of antiapoptotic gene $\mathrm{Bcl}-2$ was also observed (Fig. 6a). The graphical representation of the quantitative analysis of RT-PCR results was shown in Fig. 6b. Treatment of MDA-MB-231 cells with $\beta$-monolinolein leads to approximately 8-9-fold upregulation of $p 21,5$-fold upregulation of BID, and 3-4-fold upregulation of $B A X$. In the same way, around 4-5-fold downregulation of antiapoptotic gene $\mathrm{Bcl}-2$ was quantified after treatment with $\beta$-monolinolein at concentration of $20 \mu \mathrm{g} / \mathrm{ml}$. These results indicate that $\beta$-monolinolein leads to change in expression of various cell cycle/ apoptotic regulators and hence induces death in MDA-MB-231 cells.

\section{DISCUSSION}

Medicinal herbs have been widely accepted with escalating awareness all over the world. Nowadays, about $65 \%$ of plant-based medicines are used for cancer therapy [31]. Clinically used anticancer drugs generally induce complex responses in cancer cells [32]. Studying the mechanisms underlying these responses is important to

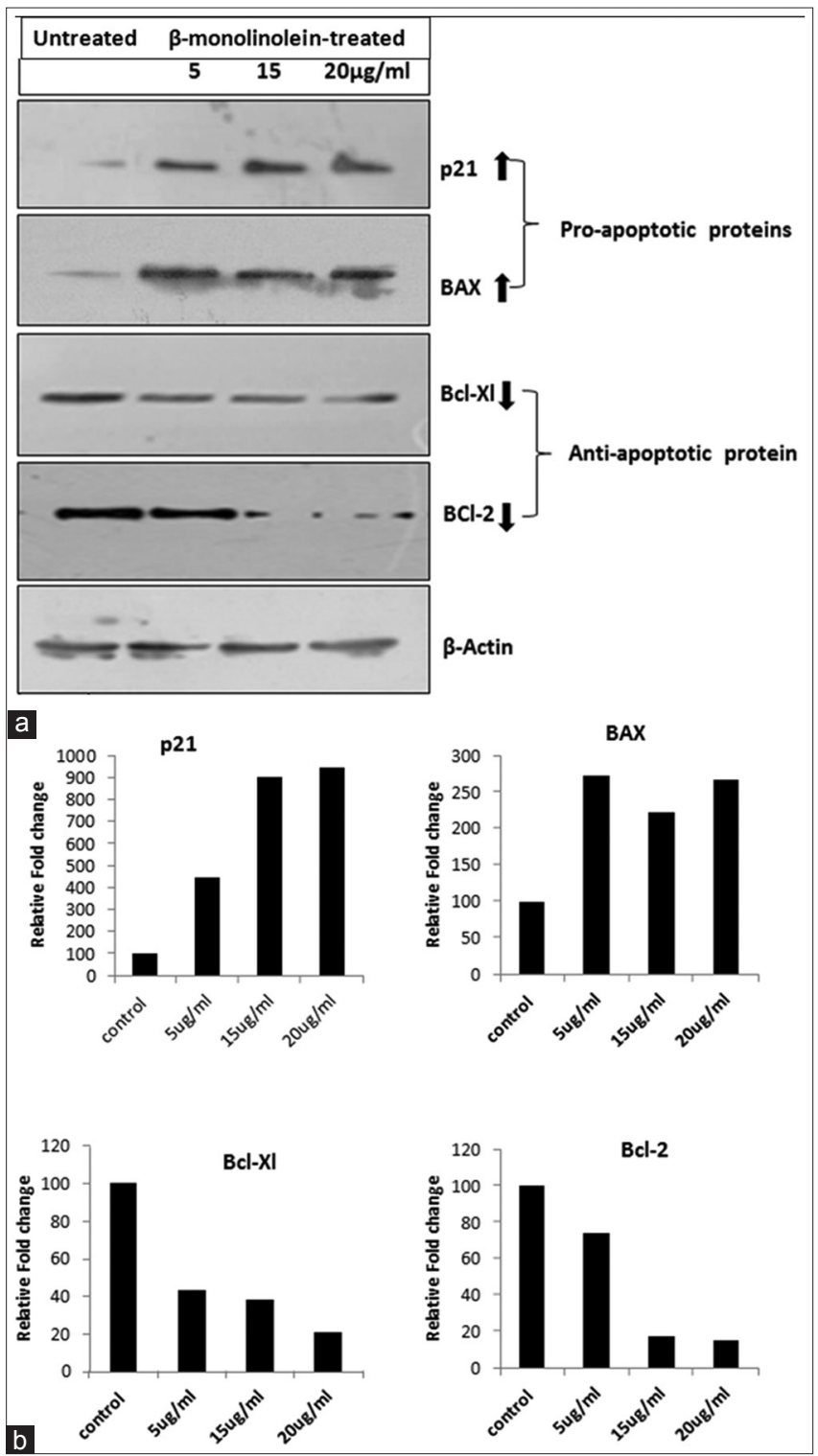

Fig. 5: Western blot analysis showing change in expression of various apoptotic and cell cycle regulators in 3,4-methylenedioxyamphetamine-MB-231 cells.

(a) Lane 1=Untreated; Lane 2-4=Cells treated with indicated concentrations of $\beta$-monolinolein, after $48 \mathrm{~h}$ of treatment.

(b) Graphs show the densitometry quantitation of the proteins indicated in the western blots understand how drugs should be optimally used and why tumor cells become resistant to them. Various forms of cancers require multiple approaches for their treatment, which opens a wide field of research in the discovery of new anticancer natural products [33]. Hence, it is important to study novel mechanisms of selected cytotoxic compounds action that could potentially represent new weapons in the fight against cancer [34]. Therefore, the continued research in this field appears to hold great promise for newer therapeutic molecules to treat cancer. Medicinal plants are the richest bioresource of drugs in traditional medicine, pharmaceutical intermediates, and chemical entities for synthetic drugs [35]. Medicinal plant extracts usually contain many secondary metabolites with varying bioactivities [36]. Several bioactive compounds have been discovered in plants and used directly as patented drugs such as taxol, artemisinin, and maprouneacin [37]. Cytotoxicity screening models provide important preliminary data to select plant extracts with potential anticancer properties [38]. In our published research work, it was found that the leaf extract of Abrus precatorius is known to consist of cytotoxic compounds that are very effective against metastatic breast cancer MDA-MB-231 cells [39]. Further, two anticancer compounds $\beta$-monolinolein and stigmasterol hemihydrate were isolated from the leaves of $A$. precatorius by various bioassayguided isolation and characterization techniques [29]. Both these compounds were experimentally proved to be having chemopreventive

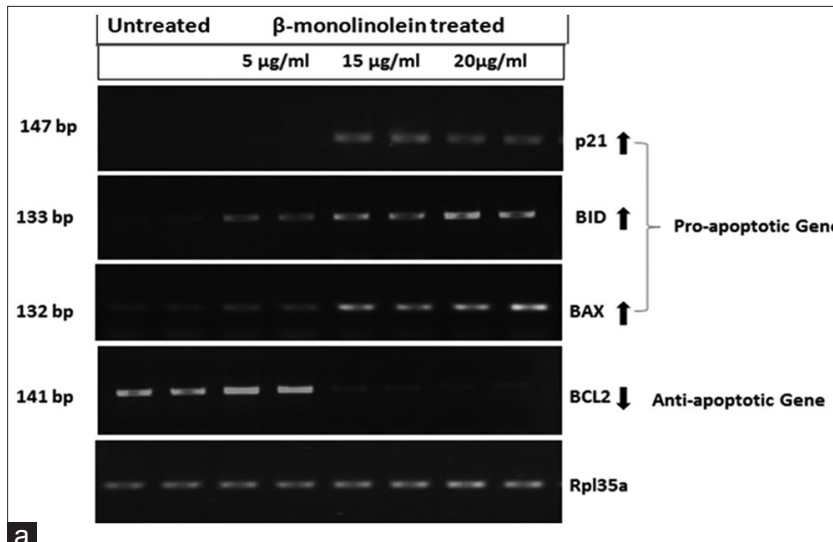

a
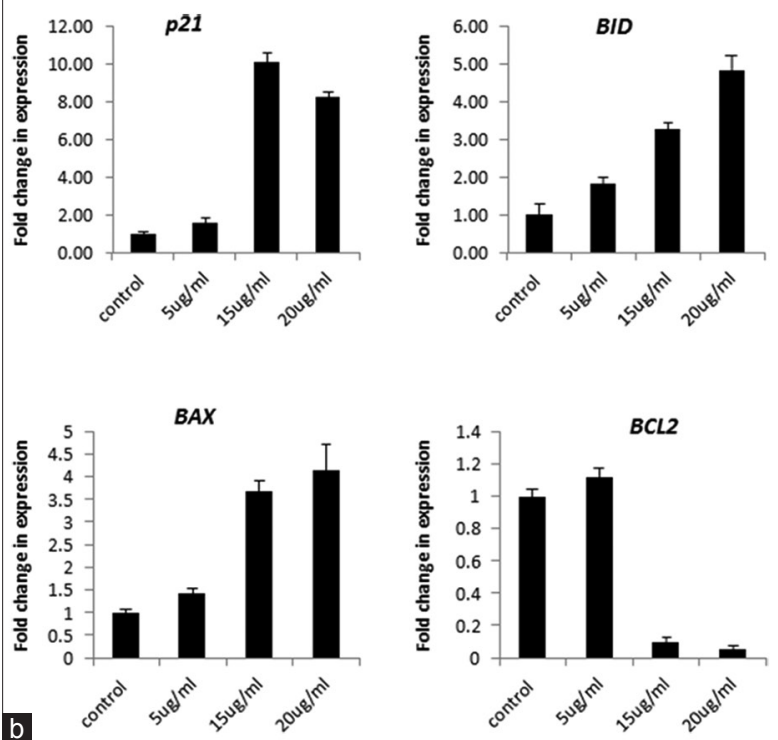

Fig. 6: Semiquantitative reverse transcription-polymerase chain reaction (RT-PCR) analysis of various cell cycle regulators,

(a) Lane 1 and 2 =Untreated; Lane 3-8=Cells treated with indicated concentrations of $\beta$-monolinolein, (b) The graphs represent the change in expression of the indicated genes as quantitated by densitometry analysis of the semiquantitative RT-PCR products 
and antibreast cancer activity both in vitro and in vivo experimental models. Now, in the present study, $\beta$-monolinolein that was having maximum cytotoxic activity was tested separately for its cytotoxic and proapoptotic activity and for molecular mechanism behind its activity on metastatic breast cancer cell line MDA-MB-231.

The $\beta$-monolinolein islong-chainunsaturated fattyacids. It was previously reported that fatty acid esters are known to exhibit cytotoxicity against HeLa, HepG2, and MCF-7 cells [40,41]. In the present investigation, for the $1^{\text {st }}$ time, it was demonstrated that $\beta$-monolinolein was found to be significantly active and inhibits growth of MDA-MB-231 cells, with an IC $_{50}$ value of $12.5 \mu \mathrm{g} / \mathrm{ml}$. More than $90 \%$ of cell death was achieved at higher concentrations after $48 \mathrm{~h}$ of treatment. Microscopic examination of MDA-MB-231 cells treated with $\beta$-monolinolein showed significant morphological changes such as shrinkage and detachment from the surface. Due to the loss of cells, differences in the cell number can also be visualized in culture dish when it was treated with $\beta$-monolinolein for $48 \mathrm{~h}$ in comparison to the control dish. These results show that $\beta$-monolinolein has a potent cytotoxic activity on breast cancer cells.

Further, trypan blue exclusion assay showed the reduction of cellviability in concentration-dependent manner in treated MDA-MB-231 cells as compared to the control cells. Another parameter for cell death is the integrity of the cell membrane which can be measured by the cytoplasmic enzyme released by damaged cells. LDH is a stable cytoplasmic enzyme abundant in the cytosol of all mammalian cells. It is rapidly released into the cell culture supernatant on damage of the plasma membrane [42]. The cytotoxicity induced by $\beta$-monolinolein was assessed by LDH leakage into the culture medium. Cell membrane rupture was defined as the ratio of LDH activity in the supernatant of treated cells to LDH activity released in the control cells. The released LDH levels were significantly elevated after $48 \mathrm{~h}$ of $\beta$-monolinolein treatment in the medium in comparison to the non-treated cells.

The western blot results showed that $\beta$-monolinolein leads to upregulation of $p 21$ and Bax proteins in a concentration-dependent manner and downregulation of $\mathrm{Bcl}-\mathrm{Xl}$ and $\mathrm{Bcl}-2$ in treated cells. Collectively the results proved that $\beta$-monolinolein has a very prominent effect on the expression levels of critical regulators of the cell cycle and apoptosis. Several studies have shown that phytochemicals such as curcumin, resveratrol, flavopiridol, indole3-carbinol, evodiamine, and green tea polyphenols are also known to induce apoptosis by downregulating expression of $\mathrm{Bcl}-2$ and $\mathrm{Bcl}-\mathrm{XL}$ in several cancer cell lines [43]. Cell cycle progression is controlled by the expression of various genes [44]. The balance between the expression of proapoptotic and antiapoptotic genes is important to determine whether cell would survive or die. Various unfavorable conditions alter the steady-state levels of these genes resulting in programmed cell death [45]. The increase in the expression of apoptotic genes leads to the release of cytochrome $\mathrm{C}$ from the mitochondria, which triggers activation of caspases that, in turn, lead to apoptosis of the cells [46]. The results showed that the treatment of MDA-MB-231 cells with the $\beta$-monolinolein regulates the expression of key cell cycle mediators in MDA-MB-231 cells. RT-PCR results indicated a significant upregulation of proapoptotic genes such as $p 53, p 21$, and Bax and downregulation of antiapoptotic gene $\mathrm{Bcl}-2$. These genes have also been demonstrated to play an important role in initiation and execution of apoptosis in tumors exposed to radiation or chemotherapy. The Bcl-2 family proteins are well known to be decisive regulators in promoting cell death [47].

\section{CONCLUSION}

Our findings suggest that $\beta$-monolinolein might prove to be a potential source of anticancer lead molecule. However, further, molecular work is still needed to validate $\beta$-monolinolein for possible anticancer drug development and the clinical purpose.

\section{CONFLICTS OF INTEREST}

We declare that we have no conflicts of interest.

\section{REFERENCES}

1. Song X, Xiong Y, Qi X, Tang W, Dai J, Gu Q, et al. Molecular targets of active anticancer compounds derived from marine sources. Mar Drugs 2018;16:175.

2. World Health Organization. World Cancer Report. Geneva, Switzerland: WHO; 2018

3. Lieu $\mathrm{CH}$, William WN, Lippman SM. Cancer chemoprevention. In: Hidalgo M, Eckhardt SG, Garrett-Mayer E, Clendeninn NJ, editors. Principles of Anticancer Drug Development. New York: Springer Science; 2010. p. 1-18.

4. Patsialou A, Wang Y, Lin J, Whitney K, Goswami S, Kenny PA, et al. Selective gene-expression profiling of migratory tumor cells in vivo predicts clinical outcome in breast cancer patients. Breast Cancer Res 2012;14:R139.

5. WHO. Cancer-Fact Sheets. WHO. Available from: http://www. who.int/mediacentre/factsheets/fs297/en/index.html. [Last cited on 2017 Jan 02].

6. Ruiz-Torres V, Encinar JA, Herranz-López M, Pérez-Sánchez A, Galiano V, Barrajón-Catalán E, et al. An updated review on marine anticancer compounds: The use of virtual screening for the discovery of small-molecule cancer drugs. Molecules 2017;22:1037.

7. Kaliberov SA, Buchsbaum DJ. Chapter seven-cancer treatment with gene therapy and radiation therapy. Adv Cancer Res 2012;115:221-63.

8. Hu Y, Fu L. Targeting cancer stem cells: A new therapy to cure cancer patients. Am J Cancer Res 2012;2:340-56.

9. Capua CJ, Hopson NP, Stewart CM, Johnston GR, O'Neill KL, Schaalje GB, et al. Cytotoxicity of Atriplex confertifolia. J Toxicol 2010;2010:976548.

10. Song YH, Sun H, Zhang AH, Yan GL, Han Y, Wang XJ. Plant derived natural products as leads to anticancer drugs. J Med Plant Herb Ther Res 2014;2:6-15.

11. George S, Bhalerao SV, Lidstone EA, Ahmad IS, Abbasi A, Cunningham BT, et al. Cytotoxicity screening of Bangladeshi medicinal plant extracts on pancreatic cancer cells. BMC Complement Altern Med 2010;10:52.

12. Russo R, Corasaniti MT, Bagetta G, Morrone LA. Exploitation of cytotoxicity of some essential oils for translation in cancer therapy. Evid Based Complement Alternat Med 2015;2015:397821.

13. Butler MS, Newman DJ. Mother nature's gifts to diseases of man: The impact of natural products on anti-infective, anticholestemics and anticancer drug discovery. Prog Drug Res 2008;65:1, 3-44.

14. Molinari G. Natural products in drug discovery: Present status and perspectives. Adv Exp Med Biol 2009;655:13-27.

15. Cragg GM, Grothaus PG, Newman DJ. Impact of natural products on developing new anti-cancer agents. Chem Rev 2009;109:3012-43.

16. Hickman JA. Apoptosis induced by anticancer drugs. Cancer Metastasis Rev 1992;11:121-39.

17. Koch S, Mayer F, Honecker F, Schittenhelm M, Bokemeyer C. Efficacy of cytotoxic agents used in the treatment of testicular germ cell tumours under normoxic and hypoxic conditions in vitro. Br J Cancer 2003;89:2133-9.

18. Carmichael J, DeGraff WG, Gazdar AF, Minna JD, Mitchell JB. Evaluation of a tetrazolium-based semiautomated colorimetric assay: Assessment of chemosensitivity testing. Cancer Res 1987;47:936-42.

19. Alami N, Paterson J, Belanger S, Juste S, Grieshaber CK, LeylandJones B, et al. Comparative analysis of xanafide cytotoxicity in breast cancer cell lines. Br J Cancer 2007;97:58-64.

20. Andersson A, Fagerberg J, Lewensohn R, Ehrsson H. Pharmacokinetics of cisplatin and its monohydrated complex in humans. J Pharm Sci 1996;85:824-7.

21. Sorenson CM, Barry MA, Eastman A. Analysis of events associated with cell cycle arrest at G2 phase and cell death induced by cisplatin. J Natl Cancer Inst 1990;82:749-55.

22. Eastman A. Activation of programmed cell death by anticancer agents: Cisplatin as a model system. Cancer Cells 1990;2:275-80.

23. Newman DJ, Cragg GM. Natural products as sources of new drugs over the last 25 years. J Nat Prod 2007;70:461-77.

24. Vadodkar AS, Suman S, Lakshmanaswamy R, Damodaran C. Chemoprevention of breast cancer by dietary compounds. Anticancer Agents Med Chem 2012;12:1185-202.

25. Wang H, Khor TO, Shu L, Su ZY, Fuentes F, Lee JH, et al. Plants vs. Cancer: A review on natural phytochemicals in preventing and treating cancers and their druggability. Anticancer Agents Med Chem 2012;12:1281-305.

26. Fabio A, Cermelli C, Fabio G, Nicoletti P, Quaglio P. Screening of the antibacterial effects of a variety of essential oils on microorganisms 
responsible for respiratory infections. Phytother Res 2007:21:374-7.

27. Villarini M, Pagiotti R, Dominici L, Fatigoni C, Vannini S, Levorato S, et al. Investigation of the cytotoxic, genotoxic, and apoptosis-inducing effects of estragole isolated from fennel (Foeniculum vulgare). J Nat Prod 2014;77:773-8

28. Steward WP, Brown K. Cancer chemoprevention: A rapidly evolving field. Br J Cancer 2013;109:1-7.

29. Sofi MS, Sateesh MK, Bashir M, Ganie MA, Nabi S. Chemopreventive and anti-breast cancer activity of compounds isolated from leaves of Abrus precatorius L. 3 Biotech 2018;8:371

30. Moongkarndi P, Kosem N, Kaslungka S, Luanratana O, Pongpan N, Neungton $\mathrm{N}$, et al. Antiproliferation, antioxidation and induction of apoptosis by Garcinia mangostana (mangosteen) on SKBR3 human breast cancer cell line. J Ethnopharmacol 2004;90:161-6.

31. Rashid MH, Bharadwaj DP, Majumder S, Mandal V, Pal M, Chandra SM, et al. Antioxidant and anticancer activity of extract and fractions obtained from Diospyros melanoxylon Roxb. Leaves and correlation with their polyphenolic profiles. Int J Pharm Pharm Sci 2018;10:6-16.

32. Banerjee S, Wang Z, Mohammad M, Sarkar FH, Mohammad RM. Efficacy of selected natural products as therapeutic agents against cancer. J Nat Prod 2008;71:492-6.

33. Boik J. Natural Compounds in Cancer Therapy. USA: Oregon Medical Press; 2001.

34. Kelloff GJ. Perspectives on cancer chemoprevention research and drug development. Adv Cancer Res 2000;78:199-334.

35. Chabner BA, Roberts TG Jr. Timeline: Chemotherapy and the war on cancer. Nat Rev Cancer 2005;5:65-72.

36. Lall RK, Syed DN, Adhami VM, Khan MI, Mukhtar H. Dietary polyphenols in prevention and treatment of prostate cancer. Int J Mol Sci 2015;16:3350-76.

37. Nirmala JM, Samundeeswari A, Sankar DP. Natural plant resources in anticancer therapy-a review. Res Plant Biol 2011;1:1-14.
38. Cardellina JH, Fuller RW, Gamble WR, Westergaard C, Boswell J, Munro MH, et al. Evolving strategies for the selection dereplication and prioritization of antitumor and HIV inhibitory natural products extracts. In: Bioassay Methods in Natural Product Research and Development. Dordrecht, Netherlands: Kluwer Academic Publishers; 1999.

39. Sofi MS, Nabi S. Induction of caspase-3 dependent apoptosis, cell cycle arrest and cytotoxicity in breast cancer cells by Abrus precatorius. Int $\mathrm{J}$ Pharm Pharm Sci 2018;10:29-35.

40. Aziz AA, Rady HM, Amer MA, Kiwan HS. Effect of some honey bee extracts on the proliferation, proteolytic and gelatinolytic activities of the hepatocellular carcinoma Hep-G2 cell line. Aust J Basic Appl Sci 2009;3:2754-69.

41. Lee SD, Guijae YE, Chae EH, Man-Jin IE, Nam-Soon OE, Yoon KH, et al. Lipid soluble extracts as the main source of anticancer activity in ginseng and ginseng marc. J Am Oil Chem Soc 2009;86:1065-71.

42. Weyermann J, Lochmann D, Zimmer A. A practical note on the use of cytotoxicity assays. Int J Pharm 2005;288:369-76.

43. Anto RJ, Mukhopadhyay A, Denning K, Aggarwal BB. Curcumin (diferuloylmethane) induces apoptosis through activation of caspase-8, BID cleavage and cytochrome c release: Its suppression by ectopic expression of bcl-2 and bcl-xl. Carcinogenesis 2002;23:143-50.

44. Surh YJ. Cancer chemoprevention with dietary phytochemicals. Nat Rev Cancer 2003;3:768-80.

45. Vogelstein B, Kinzler KW. Cancer genes and the pathways they control. Nat Med 2004;10:789-99.

46. Yang F, Oz HS, Barve S, de Villiers WJ, McClain CJ, Varilek GW, et al. The green tea polyphenol (-)-epigallocatechin-3-gallate blocks nuclear factor-kappa B activation by inhibiting I kappa B kinase activity in the intestinal epithelial cell line IEC-6. Mol Pharmacol 2001;60:528-33.

47. Ola MS, Nawaz M, Ahsan H. Role of bcl-2 family proteins and caspases in the regulation of apoptosis. Mol Cell Biochem 2011;351:41-58. 